\title{
JUSTIFICATION OF CONDITIONING VOLITIONAL DEVELOPMENT OF CHILDREN'S MASTERING THEIR LANGUAGE SKILLS AND FUNCTIONS
}

\author{
Valentyna Poul \\ Department of the preschool and primary education and the development of personality \\ Donetsk Regional Institute for Postgraduate Pedagogical Education \\ 41 Karla Marksa str., Slov'iansk, Ukraine, 84100 \\ poul@ippo.dn.ua
}

\begin{abstract}
The article analyzes the scientific approaches of domestic scientists to understanding the problem of will and the interrelated aspects of its development in ontogenesis. When studying ways of forming volitional behavior at its first stages, special attention is drawn to the fact that the child's volitional behavior arises with the emergence of the skills to build speech utterances, with which he begins to plan his activities and regulate the process of its implementation, that is, the mastering of planning and regulating functions of speech takes place. By analyzing the ways of forming language skills in preschool and early school age, structures for creation a speech utterance, the author clarified the term «expression speech» (stages of its construction) and language skills, provided for the implementation of each stage of verbal expression. Also it is justified the condition of volitional development of children mastering their language skills and functions; relationship stages of planning and regulatory functions of broadcasting in preschool and early school age. The paper presents the author's functional-structural model of the optimization process of development of the planning and regulatory functions in the formation of children's speech in their language skills.
\end{abstract}

Keywords: volitional development, speech expression, planning and regulating functions of speech, senior preschool age, primary school age.

\section{Introduction}

Relevance of the article is caused by changes in educational strategies of Ukraine [1]. According to the Concept "New Ukrainian School" it is not enough for the child to acquire knowledge. It is important to learn how to use them, have values, have life competencies required for successful fulfillment in life [2]. It is possible to provide the volitional development of children in the process of preparation for independent living and self-realization in modern society. The particular relevance of the issue is the transition from pre-school to primary school age when children acquire the skills to build their behavior in relation to the new social conditions. Therefore it is advisable to study the features of volitional development at these stages of ontogeny, and to create optimum conditions for it during the learning process.

\section{Analysis of published data and problem definition}

Research findings suggest that the development of the child will occur in different types of activities, and to form a conscious action is more important thorough testing them in the speech plan. The studying of speech as "supreme regulator of behavior" of children, was founded in 50-60 years XX century, when they discovered the value of its direct involvement in the child's self [3].

Beside the special features of studies found the special impact of adult's broadcasting on the child in the first years of life. Thus, starting from the age of two his (adult's) word receives the generalized nature, so it becomes possible to regulate the children's behavior [4]. With the age, according to research, children begin to master their actions, carrying out instructions given from adults [5]; then take actions happening with their loud speech, and then they gradually formed self-regulation based on the inner speech [6].

The factors that contribute to the capture preschool children's own behavior were studied in the works of 70-80 years. It was found that this process affects the degree of formation of their abilities to operate by verbal instruction without any sample [7]; plan their actions based on some rules [8]; distribute the activities on certain stages and execute them using external (symbolic) meanings, fixing in terms of personal responsibility for the result [9]. Each of these skills, we believe, first, 
requires from children a certain level of speech; secondly, with the expansion of instructions from adults and understanding their content created the real prerequisites for converting the external requirements surrounding the internal requirements of the preschool child to their own behavior and activities, especially gaming.

In developing problems of formation of the volitional behavior in the early school years, when it is the process of mastering the written language, a large number of works were devoted to the development of skills to manage their learning activity and their cognitive processes. It was found that the volitional development is possible with the formation of children's skills in beginning to act on teacher's verbal instruction with his/her directly control and later - based on a written scheme [10]; on the graphic schemes that reflect the semantic content of the training material to the self task of putting into effect [11]; in teaching students planning, verification and correction the activities carried out [12] etc. That is, mastering learning activity and cognitive processes, the younger students first apply to external oriented actions verbalizing them aloud (repeat the teacher's instructions), gradually moving to the inner speech "do not loud", which first becomes a meaning of self-control and self-regulation of their actions and later - planning.

Thus, in the preschool and early school years the ability to understand and follow the adult's instructions is gained, and later independently put forward the claims for himitself or herself, in our view, is the basis for the development of children's planning and regulatory functions of broadcasting.

\section{The purpose and tasks of the research}

The purpose of the article is to substantiate the volitional development of children mastering their language skills and functions.

To achieve this goal following tasks were solved:

1. To analyze the impact of the broadcasting on volitional development of preschool children and younger students and the effectiveness of the organization of their activities and behavior.

2. Clarifying the concept of «Speech statements» (stages of its construction) and language skills, provided for the implementation of each stage of verbal expression.

3. Justification of the author's functional-structural model of optimizing the process of development of the planning and regulatory functions in the formation of children's speech in their language skills.

\section{Materials and Methods}

Based on the studies identified in connection with the formation of the will of the child's speech [13], we are interested in a direction that is directly related to children's mastering speech, which in its developed form performs regulatory functions and planning of children's activities and behavior.

The regulatory function is connected with the organization and execution of human activity. The understanding of planning, supervisory, evaluative and corrective adult's applications to the child and submitting skills is the first step in the formation of its functions as the actual speech of just accompanying activities and noted its results or important items. In the second stage the child through speech interacts with peers and attracts them to the organization of joint action - the third speech is used to make their own activities [14].

Scientists examined the features of the regulatory functions of broadcasting from the first years of life, which has five forms, which gradually improved [15] (Fig. 1).

The first three forms the author attributes to external regulation, and the last two - to the inner self-regulation which is actively developing during the period of transition of the child from pre-school to primary school age. This shift from external to internal regulation of behavior, as scientists believe, contributes to the already formed planning function of speech.

The beginning of mastering speech functions as a regulator of their actions is a central feature of preschool age [16]. For instance, research shows that preschoolers distinguish the expressions intended to regulate actions with their peers in the game [17]; in the joint execution of productive [18] and labor [19] activities. Thus, the results of scientific work allowed to regard the senior preschool age as the sensitive for the establishment of the regulatory functions of broadcasting, as the verbal means of peers regulation, learned by the children, begin to carry them on their 
own activities [19]. As aforementioned components function, researchers examined the functions of planning, monitoring, evaluation and correction of their actions. They do not distinguish them as separate and independent.

\begin{tabular}{|c|c|c|c|c|}
\hline & \multicolumn{4}{|c|}{ Stages of the regulatory functions of speech } \\
\hline & \multicolumn{2}{|c|}{ External regulation } & \multicolumn{2}{|c|}{ Internal regulation } \\
\hline $\begin{array}{l}1 . \\
\text { The immediate } \\
\text { call to action }\end{array}$ & 2. Support & \begin{tabular}{|} 
3. Speech refer to \\
direct conditioned \\
stimulus \\
(substituting it with
\end{tabular} & $\begin{array}{l}\text { 4. Synthesis } \\
\text { and } \\
\text { verbalization } \\
\text { of own actions }\end{array}$ & $\begin{array}{c}5 . \\
\text { Planning for } \\
\text { future action }\end{array}$ \\
\hline
\end{tabular}

Fig. 1. The development of the child's regulatory functions of broadcasting by the research materials of V. I. Lubovsky

As for the planning function, its role in the capture of child's behavior and activities is revealed [20]; and the peculiarities of its development initially generated the surrounding: it appeals more directly to their own behavior in the form of egocentric speech and continues its emergence as an internal planning speech [21].

Some scientific papers studied the age at which the formation of the elements of planning began. For example, exploring the features of focusing the preschool children in game activity, it was found that in this age, is possible the formation of skills, to set goals, plan and execute the plan. First the child of 3-4 years is able to independently define and implement a simple objective, doing 2-3 related actions, but still not sufficiently able to perform self-control in it. The behavior of preschoolers of $4-5$ years are characterized by the ability to define different goals for the business, think over its main stages, to monitor the implementation of action. Children of 5-6 years old are able to set common goals, plan future, joint activities with peers [22].

The possibility of the action plan is based on the formation of a child's speech with a certain level [23]. This view is confirmed by the results of research of the activity patterns of children by a description of their activities in the imagined circumstances [24]. It found that high levels of regulation of the action depends on the particular child development skills to match different options of possible activities and their results which are typical for children with high levels of transmission.

But not all the children with a well-developed speech (rich vocabulary, developed sense of language) can successfully perform a volitional actions. The reasons of it are situations, high impulsivity [25] and lack of logical connections [26]. Therefore, despite the fact that school age children begin to master the action plan, they have some difficulties when you need to chart their own actions and predict their results, provide different options for the task and analyze the features of each of them.

Some aspects of child's development planning functions are considered in different situations of child's communication with adults when a loud speech, that occurs in it at the time of interacting, gradually turns into an internal, in which there are statements that precede and steer their activities, namely internal broadcasting and performs planning function [27].

Psychologists concluded that underdevelopment is an inherent capacity for the primary school children in planning and forecasting their actions [28].

Among the reasons for this situation the authors identify the skills which aborted the established causal relationships between the performance and the result of it, hypotheses of its achievements and more.

Thus, the formation of scholars' skills to plan their actions is associated with the development of children's speech during the dialogue and joint activities with others.

Based on the analysis of scientific papers we offer a possible mastering stages of development planning and regulatory functions of the older children of preschool and primary school age. Thus, in the development of speech functions from the initial stage to the next, first developed regulatory function of speech - the children are under the guidance of adults, acquire skills to analyze 
and evaluate the actions of others, based on their analysis and evaluation of adults; then - planning, senior preschool children and primary school pupils tend to own a plan of its activities, gradually learning to predict the consequences of their own actions. At this time the regulatory function continues to work, but new, more senior level - the ability to analyze and adequately evaluate the results of their actions, exercise their self-control and correction of their behavior and activities formed in children [29].

Child's development planning and regulatory functions is in the process of transformation of situational speech to the context in the message of utterance of his thoughts [30].

This process can be carried out, firstly, with the gradual change of situations of interaction with others, on the requirements of an adult to act together with their peers, then - to organize their own activities and behavior; and second, sequential transformation of features of speech in this period from foreign speech messages for other egocentric speech to support their actions in the future - to internally speech planning of their activities. The above allows us to assume that the wording of his thoughts, which are linked together and without clear interlocutor of the particular situation in which they are implemented, requires mastery of skills to build expression and learning ability of children to create their own will to optimize the development of their above speech functions.

First generation speech utterance structure includes four stages [31]. To the first author reffers the motive of expression; the second - his plan, which is a scheme of collapsed message of their views; third - inner speech, during which the plan is transferred to the system of detailed syntax of sentences; fourth - the formulation of a detailed verbal expression, which includes not one but several interconnected sentences, because it is a single integrated system and occurs during the direct contact and while transmitting the information from one person to another.

The scientist believes that, firstly, the use of a complex system of "strategies" (a term of A. R. Luria) allows a person to provide its essential values, inhibit the adverse associations and choose a speech formulation according to the task. Second, the product of expression includes the constant of monitoring its occurrence, ie speech choices of necessary components from many alternatives. According to psychologists, this choice may take the form of detailed tests, which require special effort or a smoother shape that complies previously produced circuit stages which are carefully processed.

The other structure is the creation of speech which also contained the statements of four stages, but the essence is another [32]. The first stage - motivation - means understanding the human causes that lead the speech behavior. The second - the idea - is a program or a plan. Third - implementation plan, which can occur simultaneously with the second, that is while one part is realized, the next is planned. The fourth stage is a comparison of the implementation plan by plan, ie its evaluation in terms of achieving results.

Further during the verbal statement we will mean the broadcasting directly included in the process of communication and transmission of information from one person to another and consisted of a series of interconnected sentences constituting a single integrated closed system, the occurrence of which corresponds to the five stages:

1) motivation (the goal statements);

2) plan (planning of the content of broadcasting);

3) the selection structure (forecasting of general construction);

4) implementation of sound (speech utterance formulation deployed);

5) comparing implementation of the idea with the same plan (i. e. its evaluation in terms of achieving results).

Some scientists have studied the ways of creating some language skills in preschool children, namely mastering logical consistent message of opinions [33]; developing abilities to build sentences [34] and verbal competence [35]; learning transfer [36]; create small descriptions, messages and reasons [37]; the implementation [38] and so on. The authors have not addressed the establishment of planning and regulatory functions of broadcasting in the process of learning.

As for the younger students, the research has focused on studying the speech of primary school pupils [39], examined the structure of different types of texts and statements [40], logical 
consistency between their parts [41], the formation of skills of independent analysis of works of art and creation of original texts [42] and so on. But as working with preschoolers, the relationship between the development of primary school children of language skills and mastery of their regulatory and planning functions of the speech was not a subject of their research.

Speech skills in some middle school students were carefully studied by psychologists, namely to perceive and understand other broadcasting [43], ask questions and make a plan for the content of the text [44], to build its semantic structure [45] and so on. Some studied students paid attention to the disclosure of the content of speech, others - to its structure when they were transferring the text or in the preparation of the plan, while trying to explore the possibility of constructing the expression of certain content and the structure were isolated. These observations were included in the research that determined the speech skills necessary for the process of formation and implementation of ideas, algorithm construction and implementation of verbal expression, which includes several stages. The first is the establishment of teacher's sample speech utterance; the second is the developing children's language skills of its implementation on the basis of the proposed sample; the third is generalization; the fourth is a transfer of the language skills in the new conditions [46]. But it was not studied the relationship between verbal abilities and functions in adolescents.

We offer our own functional and structural model of optimization of the development process of children planning and regulatory functions of broadcasting by training their construction of expression of different content and structure, which is shown in Fig. 2.

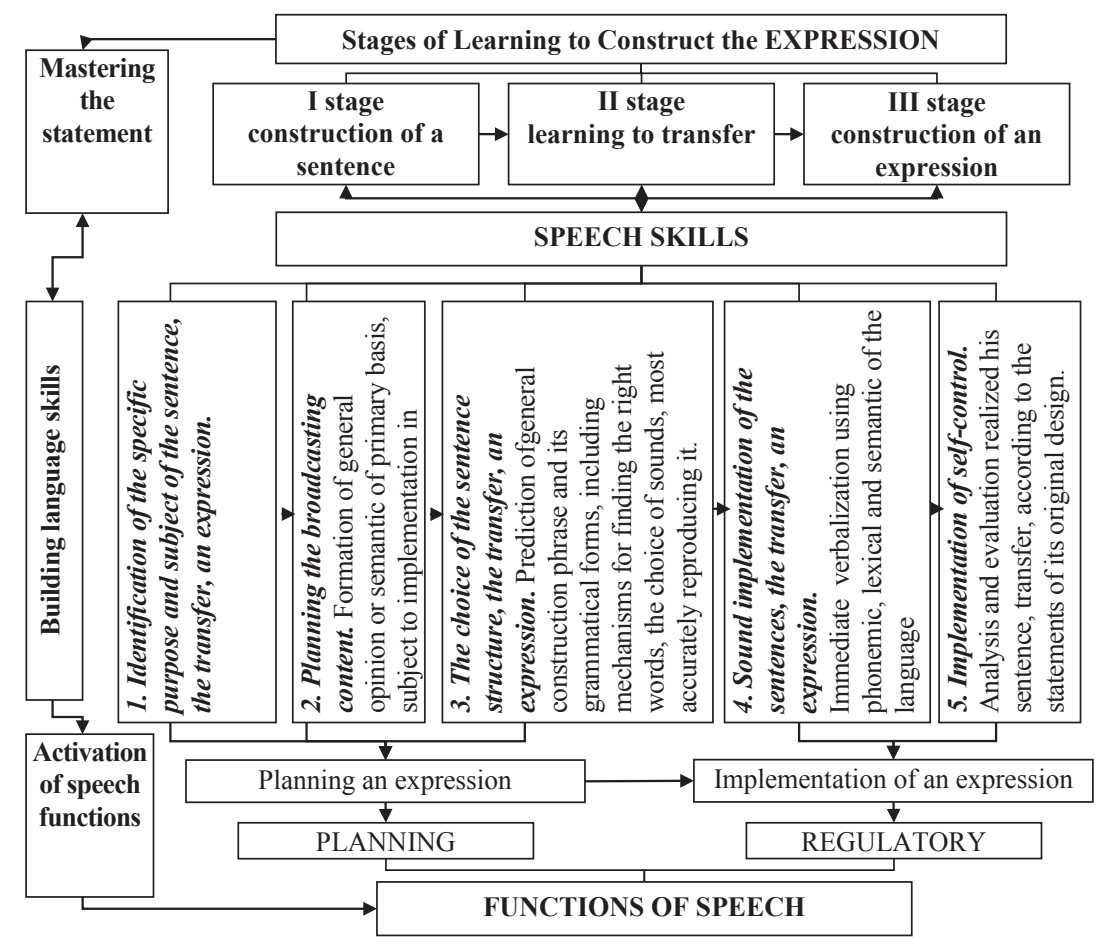

Fig. 2. Functional and structural model of optimization of the process of development planning and regulatory functions in the formation of children's speech in their language skills

Teaching children to create their own expression consists of several stages: first, to equip them with the sentence construction [47], hereinafter - the transfer of skills and only then - the ability of independent formulation of opinions [48]. In our view, the implementation of each stage requires a specific language skills, namely: defining specific goals and subject broadcast content planning, selection of its structure, followed by the sound implementation and realization of self [49]. The transition from the previous to the next stage of learning skills of children will improve, helping to optimize the process of development of their above named functions. 
Thus, at the stage of building sentences skills, content and structure are planned and reported by adult, child performs the task of carrying out the basic analysis, evaluation and correction of errors. The more diverse samples of sentences given by the teacher, the greater is the experience of children and more active become the process of development of their regulatory functions.

Further, the organization of the pedagogical process of interaction with peers, children begin to define the purpose of communicating with them, plan the content and structure of the sentence, which helps for the elementary manifestation of the planning function, while its verbalization monitor does the actions of interlocutors and, if necessary, repeats it or makes changes that indicates the transition of broadcasting regulatory functions to a higher level of implementation.

At the second stage of training the child masters the skills of transfer that, according to scientists, is an important basis for the gradual introduction of structures with different expressions. Text messaging of known content for children, based on the plan given by an adult becomes the basis for mastering skills, analysis of the work, enables them to monitor, evaluate and transfer to peer's elementary error correction, which improves the development of regulatory functions of broadcasting.

Teaching children for transfer, with scheduled plan content together with a teacher or peers, gradually contributes to the ability to think of the meaningful basis for each part, correlate the sequence and predict the overall design of their reproduction, which in turn optimize the process of the planning function.

The third is a sound of implementation of children's expression of certain content and structure with further analysis and evaluation according to the plan and development of the self-control and correction of speech and their actions, that optimizes the establishment of regulatory functions. A gradual realization of its goals encourages interaction with the children for learning to build their statements to achieve optimal relationship with them that will, no doubt, stimulate further development of the planning function.

We believe that a child's mastering of skills to identify the specific purpose and subject broadcast at every stage of planning its content and the choice of appropriate structure activates the development of planning function of speech and analysis, evaluation and correction of his remarks - regulatory. Thus, developing children's language skills above will streamline their development of planning and the regulatory functions.

\section{Results}

Thus, our theoretical review and analysis of scientific literature on the development of volitional behavior of children shows that scientists identified some ways of creating a will in the early stages of ontogeny, but poorly understood the conditionality of their mastery of speech. The scientists also found the interconnection of volition and speech processes in preschool and primary school children, but changes in the dynamics of development in these age periods are not investigated. Psychologists observed dependence of the formation of regulatory and planning functions of the speech on the appearance of a child to build its skills of expression, but not investigated the role of language skills in the development of these functions. Scientists also point to the speech communication function with the development of volitional behavior, yet they have not sufficiently studied the characteristics of their role in the development and volitional development of children. The development of children's abilities to build speech statement in connection with the development of their speech functions and the development of their volitional behavior has not been the subject of research issues.

All this allows us to speculate that because the speech takes planning and regulatory functions to self-regulation behavior in children, the optimization of their volitional activation process is possible due to the formation of these functions by forming their skills of the self-expression coherent construct. We believe that targeted training of the senior preschool and primary school children in modeling of connected speech utterances of different content and structure will facilitate the optimization process of development of their regulatory and planning functions of speech, which is the psychological conditions for children's development of the ability to design their own volitional behavior [50]. 


\section{Discusion of the results}

These results are the basis for the development of specific methods of teaching preschool and primary school age children of self-constructing coherent expressions to enhance the process of establishing their planning and regulatory functions of broadcasting, which will help to optimize their volitional development. It is based on the idea of our study of the growth for the regulatory role of speech in the organization and implementation of child's activities and implementation of their own behavior.

Volitional child's behavior stems from the emergence of skills to build speech utterances, when with its help he/she begins to make a plan of his/her activities and regulate the process of its implementation, there is the development of planning and regulatory functions of broadcasting. We focuses on creating and further developing the testing program aimed at the development of the speech functions of older preschool and primary school age children.

\section{Conclusions}

We conducted the theoretical analysis of the scientific literature regarding psychological conditioning of volitional development of children of preschool and primary school age, development of their language skills and functions that allows the following conclusions:

1. The modern psychology focuses on the impact of adult speech and speech self support of children in their own actions on the efficiency and organization of behavior as preschoolers and students of all ages.

2. Correlation of volitional and speech processes in preschool and early school age; it was found that the transmission performs regulatory, planning functions in the exercise of their behavior and activity. Thus, the child first begins to operate regulatory function - it behaves, referring to the requirements and guidance of an adult, then - planning seeks for making the plan of its actions in the activity independently, as reflected in the construction of its own expression. But scientists have not studied this relationship changes in the dynamics of freedom and speech in the early stages of ontogeny.

3. Researchers developed the issues of developing children's abilities with independent construction speech utterances, but not studied the relationship of such studies with the development of pre-school children and primary school pupils' planning and regulatory functions of broadcasting.

\section{Acknowledgments}

Great words of respect and sincere gratitude for the wise mentoring, support and understanding of my head, my scientific mentor, inspiration and best adviser, Lesya Ivanovna Voloshenko, the candidate of psychological sciences, in carrying out the study. She is not side by side, but her memory, her ideas are always with us.

\section{References}

[1] Hryshchenko, M. (Ed.) (2016). Nova ukrayins'ka shkola: Kontseptsiya novoyi ukrayins'koyi shkoly. 136. Available at: http://mon.gov.ua/\%D0\%9D\%D0\%BE\%D0\%B2\%D0\%B8\%D0\%BD\%D0\%B8\%20 2016/12/05/konczepcziya.pdf

[2] Proekt Zakonu pro osvitu № 3491-d (2016). Available at: http://w1.cl.rada.gov.ua/pls/zweb2/webproc4_1?pf3511=58639

[3] Luryya, A. R., Yudovych, F. Ya. (1956). Rech' y razvytye psykhycheskykh protsessov u rebenka: Eksperymental'noe yssledovanye. Moscow: APN RSFSR, 94.

[4] Gradova, A. P. (1995). Ekonomicheckaja stpategija firmy. Saint Peterburg: social'naja literatura, 414.

[5] Tihomirov, O. K. (1958). O formirovanii proizvol'nyh dvizhenij u detej doshkol'nogo vozrasta. Problemy vysshej nervnoj dejatel'nosti normal'nogo i anomal'nogo rebenka. Moscow: ANP RSFSR, 420.

[6] Kupcov, I. I. et. al. (Eds.) (1991). Problemy psihologii. Rjazan’: B. I. RGPI, 191.

[7] Kotyrlo, V. K. (1971). Razvitie volevogo povedenija u doshkol'nikov. Kyiv: Rad. shk., 199.

[8] Pereverzeva, V. M. (1981). Psihologicheskij analiz prjamyh i kosvennyh form reguljacii povedenija detej doshkol'nogo vozrasta. Kyiv, 24.

[9] Shibitskaja, L. A. (1973). Formirovanie samoreguljacii povedenija starshih doshkol'nikov. Kyiv, 26. 
[10] Didora, M. I. (1982). Formirovanie samostojatel'nosti mladshih shkol'nikov v processe obuchenija. Kyiv, 23.

[11] Jachina, A. S. (1982). Formirovanie soznatel'no-reguliruemyh sposobov zapominanija i vosproizvedenija v processe obuchenija mladshih shkol'nikov. Kharkiv, 19.

[12] Derkach, L. N. (1994). Psihologicheskie osnovy samokontrolja uchashhihsja v processe obuchenija inostrannym jazykam. Kyiv, 20.

[13] Poul', V. S. (2006). Problema stanovlennja voli v ontogenezi. Visnik HNPU im. G.S. Skovorodi. Psihologija, 16, 110-117.

[14] Vygotskij, L. S., Eds. Zaporozhec, A. V., Davydov, V. V. (1982). Sobranie sochinenij: Myshlenie i rech'. Moscow: Pedagogika, 502.

[15] Lubovskyy, V. Y. (1978). Razvytye slovesnoy rehulyatsyy deystvyy u detey. Moscow: Pedahohyka, 224

[16] Markova, A. K. (1974). Psihologija usvoenija jazyka kak sredstva obshhenija. Moscow, 52.

[17] Karpova, S. N., Stepanova, M. A. (1984). Osobennosti svjaznoj rechi doshkol'nikov pri obshhenii so vzroslym i sverstnikom. Vestnik Moscow university, 4, 21-28.

[18] Karpova, S. N., Ahundzhanova, S. A. (1983). Osobennosti razvitija form i funkcij rechi doshkol'nika v razlichnyh situacijah obshhenija. Kategorii, principy i metody psihologii. Moscow, 651-653.

[19] Samoshkina, L. N. (1995). Razvitie funkcij i form rechi doshkol'nikov. Dnipropetrovsk: DDU, 52.

[20] Vygotskij, L. S., Eds. Zaporozhec, A. V., Davydov, V. V., Lurija, A. R. (1983). Sobranie sochinenij: Problemy razvitija psihiki. Moscow: Pedagogika, 502.

[21] Levina, R. E. (1968). Idei L.S. Vygotskogo o planirujushhej rechi rebenka. Voprosy psihologii,

[22] Vazina, K. Ja. (1979). Osobennosti projavlenija celeustremlennosti u doshkol'nikov v igrovoj dejatel'nosti. Voprosy psihologii voli, 18-30.

[23] Subbotskij, E. V. (1976). Psihologija otnoshenij partnerstva u doshkol'nikov Moscow: Izdatelstvo Moscow university, 144.

[24] Daunis, I. B. (1986). Svjaz' urovnja celevoj reguljacii dejstvija i lichnostnyh harakteristik u doshkol'nikov. Voprosy psihologii, 3, 44-52.

[25] Bastun, N. A. (1992). Psykholohichnyy analiz prychyn nyz'koyi uspishnosti navchannya shestyrichnykh pershoklasnykiv. Kyiv, 15.

[26] Polishchuk, V. M. (1995). Psykholohichni osoblyvosti ditey perekhidnoho periodu vid doshkil'noho do molodshoho shkil'noho viku. Kyiv, 25.

[27] Volkov, B. S., Volkova, N. V. (2003). Psykholohyya obshchenyya v det-skom vozraste. Moscow: Pedahohycheskoe obshchestvo Rossyy, 240.

[28] Rehush, L. A. (2003). Psykholohyya prohnozyrovanyya: uspekhy k poznanyyu budushcheho. Saint Peterburg: Rech', 352.

[29] Poul', V. S. (2015). Vzayemozv»yazok etapiv stanovlennya rehulyatyvnoyi ta planuval'noyi funktsiy movlennya u ditey. Providna rol' osvitn'oho dosvidu v stanovlenni osobystosti. Available at: http:// distance.dnu.dp.ua/ukr/conference/2015/aspecty/Poul.pdf

[30] Lisina, M. I. (1986). Problemy ontogeneza obshhenija. Moscow: Pedagogika, 144.

[31] Lurija, A. R. Eds. Homskoj, E. D. (1998). Jazyk i soznanie. Rostov na Dony: Feniks, 416.

[32] Leont'ev, A. A. (1969). Psiholingvisticheskie edinicy i porozhdenie rechevogo vyskazyvanija. Moscow: Nauka, 307.

[33] Vojtko, L. F. (1970). Osobennosti formirovanija dokazatel'stv u detej doshkol'nogo vozrasta. Kyiv, 16.

[34] Bogush, A. M., Gavrish, N. V. (2007). Doshkil'na lingvodidaktika: Teorija i metodika navchannja ditej ridnoï movi. Kyiv: Vishha shk., 542.

[35] Bohush, A. M. (2000). Teoretychni y metodychni zasady formuvannya movlennyevoyi kompetentsiyi doshkil'nyka. Pedahohika i psykholohiya, 1, 5-10.

[36] Ushakova, T. N., Belova, S. S., Gromova, O. E. (2008). Rannee rechevoe razvitie i ego prirodnye osnovanija. Voprosy psihologii, 2, 44-56.

[37] Harchenko, N. (2001). Formuvannja navichok mirkuvannja u ditej 5-6 richnogo viku. Doshkil'ne vihovannja, 2, 18-20. 
[38] Bila, I. M. (2006). Rozvytok stratehichnykh tendentsiy analohizuvannya v tvorchiy diyal'nosti starshykh doshkil'nykiv. Kyiv, 21.

[39] Starahina, I. P. (2000). Pro movnyy rozvytok molodshykh shkolyariv. Pedahohika i psykholohiya. $1,10-16$.

[40] Lokalova, N. P. (2000). Organizacija verbal'no-smyslovoj kognitivnoj struktury. Voprosy psihologii, 5, 72-86.

[41] Voloshenko, L. I. (1992). Razvitie produktivnyh funkcij pamjati u mladshih shkol'nikov v processe usvoenija semanticheskoj i logicheskoj struktury tekstovoj informacii. Kharkiv, 15.

[42] Skorynina, O. V., Khomulenko, T. B. (2003). Kohnityvnyy styl' i pam»yat': paradoksy doslidzhennya. Kharkiv: VD «INZhEK», 232.

[43] Antonjuk, N. S. (1977). Sravnitel'naja harakteristika ponimanija uchashhimisja rechevoj informacii v zavisimosti ot sposoba ee vosprijatija. Kyiv, 26.

[44] Surkov, Ju. V. (1970). Samostojatel'naja postanovka uchashhimisja voprosov k tekstu uchebnika kak odin iz priemov samokontrolja. Saratov: Izdatel'stvo Saratovskogo universiteta, 49-59.

[45] Tokareva, N. M. (1997). Osoblyvosti formuvannya v uchniv seredn'oho viku pryyomiv pobudovy smyslovoyi struktury tekstu. Kyiv, 24.

[46] Vasil'eva, V. N. (1980). Formirovanie processual'noj storony samostojatel'nosti shkol'nikov v obuchenii rechevoj dejatel'nosti. Kazan', 21.

[47] Leushina, A. M. (1941). Razvitie svjaznoj rechi u doshkol'nika. Psihologija rechi: uchenye zapiski, 35, 21-72.

[48] Skalkin, V. L. (1983). Obuchenie monologicheskomu vyskazyvaniju (na materiale anglijskogo jazyka). Kyiv: Radjans'ka shkola, 119.

[49] Poul', V. S., Voloshenko, L. I. (2012). Osoblyvosti navchannya ditey pobudovi zv»yaznykh vyslovlyuvan'. Veresen', 3-4, 78-85.

[50] Poul', V. S. (2014). Psykholohichni umovy rozvytku vol'ovoyi povedinky u ditey starshoho doshkil'noho ta molodshoho shkil'noho viku. Kharkiv: Natsional'nyy pedahohichnyy universytet imeni H. S. Skovorody, 20. 